\title{
The molecular epidemiology of Salmonella Typhi across Indonesia reveals bacterial migration
}

\author{
Lucky H. Moehario
}

Department of Microbiology, Faculty of Medicine, University of Indonesia, Jalan Pegangsaan Timur 16, Jakarta 10320, Indonesia

\begin{abstract}
Background: Typhoid fever remains a worldwide problem, but it is particularly common in Southeast Asia, including Indonesia. The causative agent Salmonella Typhi is known to have significant genome plasticity.

Methodology: This study describes genetic fingerprints using restriction fragment length polymorphism with SpeI of chromosomal DNA and pulsed-field gel electrophoresis (PFGE) of $S$. Typhi isolated from different geographic areas spreading from west to east across Indonesia.

Results: A total of 33 SpeI digested S. Typhi chromosomal DNA gave 22 schizotypes, 20 pulsotypes, and 12 subtypes indicating genomic diversity and the presence of more than one clone of $S$. Typhi. Cluster analysis at a degree of similarity of $\geq 80 \%$ showed four clusters, three of which were associated with geographic area. One cluster (Dice coefficient 0.727-1.000) contained isolates from three different geographic areas (Jakarta, Makasar, Jayapura), spread across Indonesia.

Conclusions: Genetic fingerprinting of $S$. Typhi in Indonesia showed the presence of endemic strains in localized geographic areas, as well as the movement of one strain type throughout the archipelago.
\end{abstract}

Key words: Salmonella Typhi, Typhoid fever, pulsed-field gel electrophoresis, molecular epidemiology

J Infect Dev Ctries 2009; 3(8):579-584.

Received 4 April 2009 - Accepted 13 July 2009

Copyright (C) 2009 Moehario. This is an open-access article distributed under the Creative Commons Attribution License, which permits unrestricted use, distribution, and reproduction in any medium, provided the original work is properly cited.

\section{Introduction}

Typhoid fever is a major health problem in Southeast Asian countries including Malaysia, Thailand, and Indonesia [1]. In 2007, the Communicable Disease Centre (CDC) of Indonesia reported a prevalence of $358-810$ per 100,000 population for typhoid fever with $64 \%$ occurring in 3- to 19-year olds [2]. In South Sulawesi, the case detection rate increased from 257 per 100,000 population in 1991 to 386 per 100,000 population in 2007 [3]. In Jakarta, typhoid fever was the second leading infectious disease after gastroenteritis and caused the highest mortality [4]. The mortality rate varied from 3.1-10.4\% among hospitalized patients [2] with cases occurring throughout the year but peaking in the dry season. In rural areas there are probably many cases that remain undiagnosed due to limited diagnostic facilities. Studies of the molecular epidemiology of $S$. Typhi have been conducted since the early nineties using pulsed-field gel electrophoresis (PFGE) and have shown significant genetic diversity of $S$. Typhi isolates both from outbreaks and sporadic cases of typhoid fever $[5,6,7,8,9]$. An increase in the number of people who travel domestically and internationally also provides a means by which $S$. Typhi can migrate from one place to another, and may contribute to the emergence of new strains of $S$. Typhi. Previous investigations showed the existence of multiple strains of $S$. Typhi in Jakarta which simultaneously co-existed causing endemic and sporadic disease $[7,10,11]$. In this study we used PFGE to analyze the genetic diversity of $S$. Typhi isolates originating from patients with typhoid fever from five different geographic areas across Indonesia.

\section{Methods}

The investigation was conducted in the laboratory of the Department of Microbiology in the Faculty of Medicine at the University of Indonesia in Jakarta.

\section{Bacterial isolates}

$S$. Typhi isolates were taken from collections stored in the Department of Microbiology, Faculty of Medicine, at the University of Indonesia, and from the Center of Health Research and Development, Ministry of Health, Republic of Indonesia. Out of a total of $33 S$. Typhi isolates, 10 isolates originated from sporadic typhoid fever cases in Jakarta (JKT), 9 from Pontianak (PON), 3 from Makasar (MKR), 10 from Jayapura (JPR) and one from Medan (MDN). All isolates were retested using standard biochemical reactions, and commercial slide agglutination from Biofarma Indonesia. Susceptibility of the bacteria to 
Figure 1. Map of Indonesia showing the locations from which $S$. Typhi was obtained for this study from West to East regions

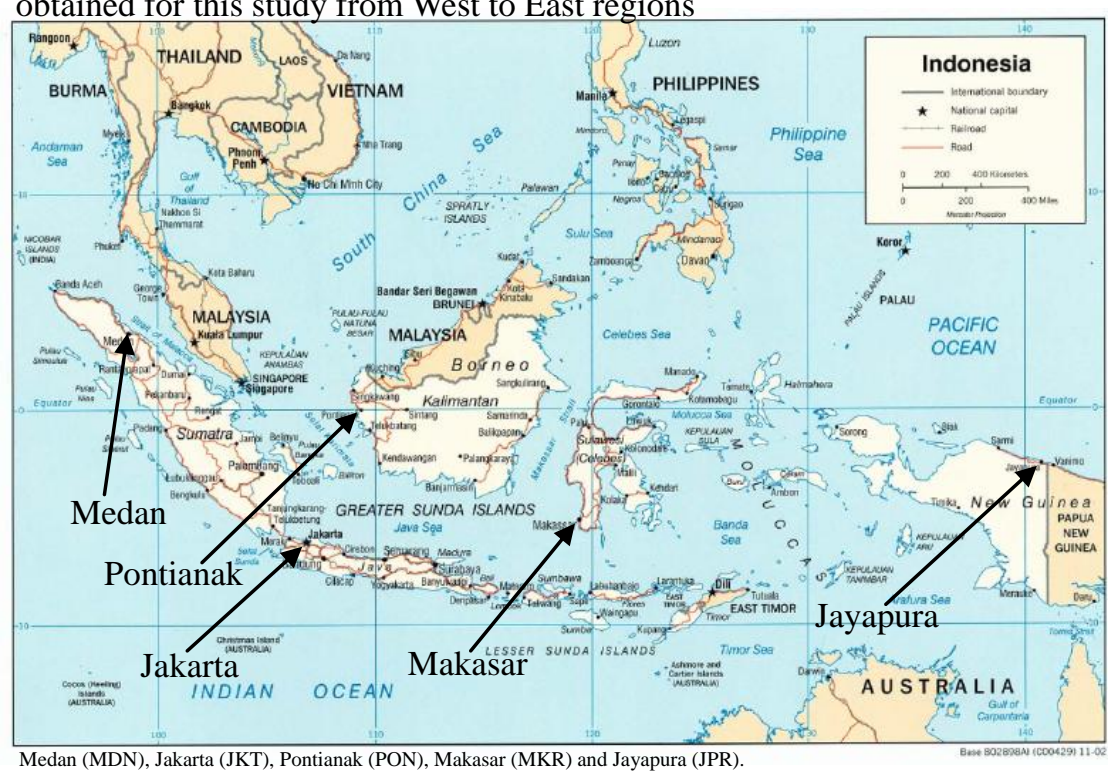

antibiotics was examined using the disc diffusion method. The five cities from which the isolates were obtained are located in different islands. Medan, Jakarta and Pontianak are located in Sumatra, Java and Kalimantan Islands respectively, which are all in West Indonesia. Makasar is located in Sulawesi Island, which is in Central Indonesia, and Jayapura is in Papua, which is in East Indonesia (see Figure 1).

\section{Pulsed-Field Gel Electrophoresis (PFGE) and Genome Analysis}

Preparation of the DNA genome was conducted as described earlier by Suwanto and Kaplan [12] and Thong et al. [5]. Pulsed-field gel electrophoresis (PFGE) of SpeI (5' ACTAGT-3') digested chromosomal DNA was performed as in Moehario and Soemanto [10], in which PFGE CHEF-DR II (Bio-Rad Laboratories, Richmond, California, USA), program 17(50-900) for Salmonella sp. was used. Electrophoresis was performed at $14^{\circ} \mathrm{C}$ for approximately 19.5 hours with pulse time 5.3 to 60 seconds and electrical current of 6 volt per $\mathrm{cm}^{2}$. DNA restriction patterns resulting from rare-cutting endonuclease were designated as schizotypes (Suwanto and Kaplan) [13]. Interpretation of the PFGE patterns was performed as described earlier by Bannerman et al.[14] and assigned for arbitrary pattern types and compared by calculating Dice similarity coefficient. PFGE type (pulsotype) and subtype were based on criteria by Bannerman et al. [14] and Zadoks et al., [15]. S. Typhi isolates showing the same PFGE patterns or differing by one to three bands were grouped in the same types while those with PFGE patterns differing up to four to six bands were grouped as closely related types. Different or unrelated types were determined if
PFGE patterns differed by seven bands or more. The designation of subtypes was used for those which had up to three PFGE band differences. A cluster analysis was performed using unweighted pair group arithmetic means method (UPGMA) of Dice coefficient for all pairs of strains, and a phenogram was generated using the computer program Numerical Taxonomy and Multivariate Analysis System (NTSYS-pc) version 1.80 (Rohlf) [16].

\section{Results}

A total of 33 chromosomal DNA extractions from $S$. Typhi digested with SpeI restriction endonuclease were analyzed after electrophoresis using a CHEF-DR II machine (BioRad, USA). The DNA profiles of these isolates showed PFGE patterns with distinctive differences according to their regions, i.e., Jakarta, Pontianak, Makasar, Jayapura and Medan. The electrophoresis fragments were unique for each of the isolates and therefore they are the fingerprints for each of them. Nonetheless, all the $S$. Typhi isolates showed similar phenotypes in that they were susceptible to three antibiotics tested, i.e., Chloramphenicol, Ampicilin and Cotrimoxazole. The digestion of the DNA genome with SpeI resulted in 12 to 23 DNA fragments with molecular weight ranges between 29 and 1,100 kb. Estimated genome size varied from 1,495 up to $4,516 \mathrm{~kb}$.

Genetic similarity and dissimilarity of $S$. Typhi were examined. Ten $S$. Typhi isolates from Jakarta showed close genetic relatedness except for one isolate. Cluster analysis showed that nine isolates (JKT1, JKT3, JKT2, JKT5, JKT4, JKT10, JKT6, JKT7 and JKT8) were closely related and grouped together in group IA1 (see Figure 2). Dice coefficients of these isolates ranged from 0.737 to 
Figure 2. Phenogram of $33 S$. Typhi isolates from five different geographic areas of Indonesia

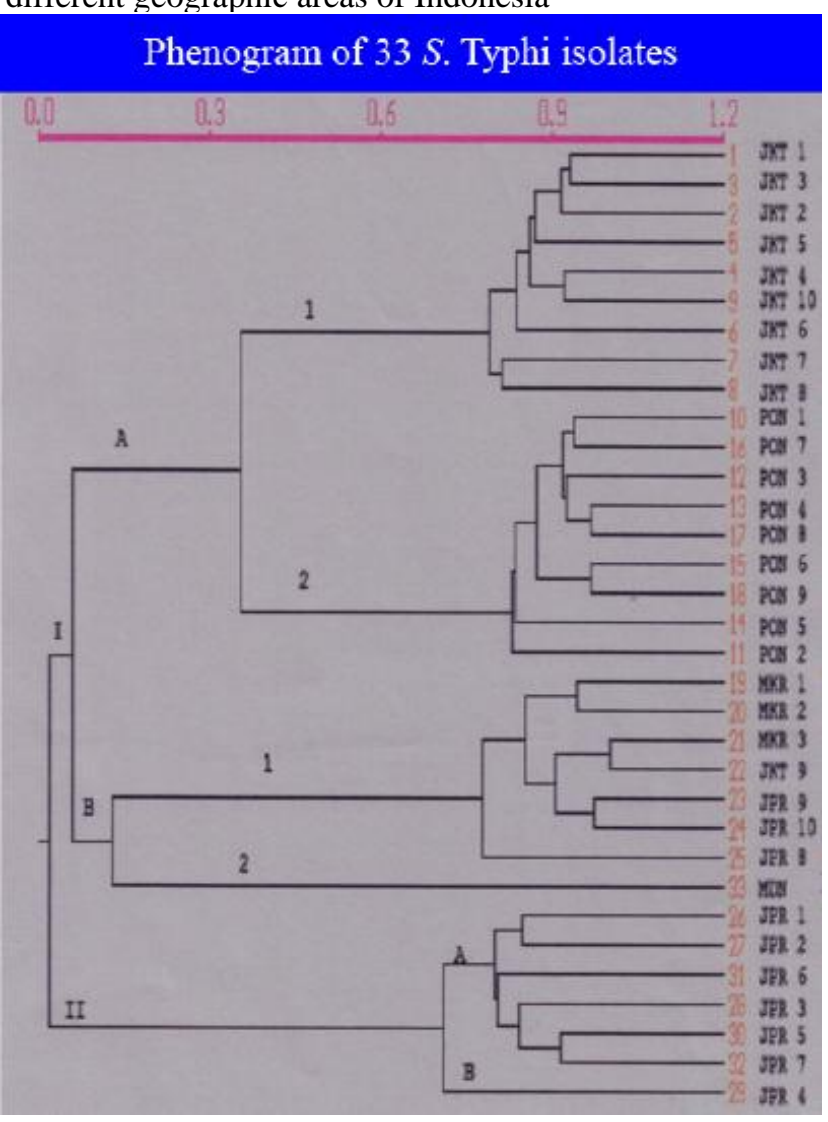

Jakarta (JKT), Pontianak (PON), Makasar (MKR), Medan (MDN), Jayapura (JPR)

0.930. JKT9 had a different PFGE profile from the other nine isolates, with Dice coefficients $0.143-0.205$. At the $\geq 80 \%$ degree of similarity, all 10 JKT isolates gave $F$ value ranging from $0.143-0.930$. The cluster analysis demonstrated that JKT9 did not share genetic relatedness with the other nine isolates, and therefore it is unlikely that it originated from Jakarta. Nine $S$. Typhi isolates from Pontianak all gave closely related PFGE patterns, and they were all clustered in IA2 (Figure2). All nine isolates had Dice coefficients ranging from 0.765-0.968 thus suggesting these isolates were homogenous. Three $S$. Typhi isolates from Makasar were also very closely related with Dice coefficients 0.857-0.941. All the Makasar isolates (MKR1, MKR2, and MKR3) were grouped in cluster IB1 together with isolates derived from other areas as follows: JKT9 from Jakarta; JPR9, JPR10, and JPR8 from Jayapura (Figure 2). These seven isolates seemed to be closely genetically related ( $\mathrm{F}$ value $0.727-0.971$ ). One isolate from Medan (MDN) was included in cluster IB2. It was dissimilar to those in cluster IB1, and the Dice coefficient was 0.125-0.138. Six of the $S$. Typhi isolates from Jayapura (JPR1, JPR2, JPR6, JPR3, JPR5, and JPR7) were clustered together in cluster IIA and seemed to be closely related with Dice coefficients 0.774-0.941. JPR4, however, showed an F value of 0.621-0774 to those six isolates, and thus was grouped by itself in IIB. At the $\geq 80 \%$ degree of similarity, all 10 isolates from Jayapura had diverse genome profiles, with $\mathrm{F}$ values ranging from $0.000-0.971$. Three isolates of Jayapura (JPR 8, JPR9, and JPR10) apparently were not related to those in cluster IIA and IIB, which is shown by their Dice coefficients (0.000-0.069). The genetic fingerprints for ten $S$. Typhi isolates of Jayapura showed that although the bacteria had originated from the same area, they might not have derived from the same ancestor. The Dice coefficient for all S. Typhi isolates from five different geographic areas across Indonesia ranged from $0.000-0,971$ thus indicating the heterogeneity of $S$. Typhi in the country.

Of all 33 isolates of $S$. Typhi, 22 schizotypes, 20 pulsotypes and 12 subtypes were found (see Table 1). $S$. Typhi isolates included in cluster I A1 exhibited six schizotypes, six pulsotypes, and three subtypes, while those in cluster I A2 had six schizotypes, four pulsotypes, and five subtypes. Cluster I B1, consisting of collections of schizotypes from $S$. Typhi isolates from three areas (Makasar, Jakarta and Jayapura) revealed four schizotypes, four pulsotypes, and two subtypes. Interestingly, two $S$. Typhi isolates originating from two different areas, Makasar and Jakarta, were identical (Table 1). These two isolates, JKT9 and MKR3, might have originated from one clone. Cluster II A exhibited four schizotypes, four pulsotypes, two subtypes and one schizotype, while cluster II B exhibited one pulsotype.

\section{Discussion}

A total of 33 isolates of $S$. Typhi were examined. The isolates originated from five locations in three regions of Indonesia: the west region (Medan, Jakarta, Pontianak); the central region (Makasar); and the east region (Jayapura). All 33 isolates were examined for their genetic relatedness using PFGE. Numbers of DNA fragments obtained in this study were similar to those of our previous study of genomic digestion by $X b a \mathrm{I}[10,11]$. DNA fragments with molecular weight $97 \mathrm{~kb}$ and lower remained consistent, while DNA fragments between 97-360 kb and above 360 $\mathrm{kb}$ were varied $[10,11]$. Genome size of these isolates was varied from 1,495 up to $4,516 \mathrm{~kb}$. The smallest genome size was found in the $S$. Typhi isolate originating from Jayapura (JPR) and the largest was the isolate from Jakarta (JKT). Thong et al. used three different restriction enzymes, XbaI, AvrII, and SpeI, and found that the genome sizes of $S$. Typhi differed by as much as $959 \mathrm{~kb}$, ranging from 3,964 to $4,923 \mathrm{~kb}$ (mean genome size 4,528 kb) [17]. Pang [9] reported the analysis of $S$. Typhi genomes derived 
Table 1. Schizotypes and Pulsotypes of Salmonella Typhi genome digested with SpeI

\begin{tabular}{|c|c|c|c|c|}
\hline Clusters & Isolates & Schizotypes & Pulsotypes & Subtypes \\
\hline I A1 & $\begin{array}{lr}\text { JKT } & 1 \\
\text { JKT } & 3 \\
\text { JKT } & 2 \\
\text { JKT } & 5 \\
\text { JKT } & 4 \\
\text { JKT } & 10 \\
\text { JKT } & 6 \\
\text { JKT } & 7 \\
\text { JKT } & 8\end{array}$ & $\begin{array}{l}1 \\
1 \\
2 \\
3 \\
4 \\
4 \\
5 \\
6 \\
6\end{array}$ & $\begin{array}{l}1 \\
\\
2 \\
3 \\
4 \\
5 \\
6\end{array}$ & $\begin{array}{l}1.1 \\
1.2\end{array}$ \\
\hline I A2 & $\begin{array}{l}\text { PON } 1 \\
\text { PON } 7 \\
\text { PON } 3 \\
\text { PON } 4 \\
\text { PON } 8 \\
\text { PON } 6 \\
\text { PON } 9 \\
\text { PON } 5 \\
\text { PON } 2\end{array}$ & $\begin{array}{c}7 \\
7 \\
8 \\
9 \\
9 \\
10 \\
10 \\
11 \\
12\end{array}$ & $\begin{array}{l}7 \\
\\
\\
8 \\
9 \\
10\end{array}$ & $\begin{array}{l}7.1 \\
7.2 \\
7.3 \\
7.4 \\
\\
8.1\end{array}$ \\
\hline I B1 & $\begin{array}{lr}\text { MKR } & 1 \\
\text { MKR } & 2 \\
\text { MKR } & 3 \\
\text { JKT } & 9 \\
\text { JPR } & 9 \\
\text { JPR } & 10 \\
\text { JPR } & 8\end{array}$ & $\begin{array}{l}13 \\
13 \\
14 \\
14 \\
15 \\
15 \\
16\end{array}$ & $\begin{array}{l}11 \\
12 \\
12 \\
13 \\
\\
14\end{array}$ & $\begin{array}{c}11.1 \\
\text { identical } \\
\text { identical } \\
13.1\end{array}$ \\
\hline I B2 & MDN & 17 & 15 & \\
\hline II A & $\begin{array}{cc}\text { JPR } & 1 \\
\text { JPR } & 2 \\
\text { JPR } & 6 \\
\text { JPR } & 3 \\
\text { JPR } & 5 \\
\text { JPR } & 7\end{array}$ & $\begin{array}{l}18 \\
18 \\
19 \\
20 \\
21 \\
21\end{array}$ & $\begin{array}{l}16 \\
17 \\
18 \\
19\end{array}$ & $\begin{array}{r}16.1 \\
19.1\end{array}$ \\
\hline II B & JPR 4 & 22 & 20 & \\
\hline
\end{tabular}


from many countries including Indonesia, Papua New Guinea, Chile, and Malaysia. The genome size of S. Typhi from Indonesia was 4,750-4,860 kb, from Papua New Guinea it was 3,980-4,180 kb, from Chile it was 4,330-4,660 kb, and from Malaysia it was 4,620-4,870 kb. Differences in genome size were probably due to genetic events such as chromosome rearrangements and mutations; nonetheless, area of origin might also be considered. The S. Typhi genome has been shown to rearrange more frequently compared to other enteric bacteria during evolution $[18,19]$. PFGE has been used in many studies to show the presence of genome diversity and confirm genomic plasticity of S. Typhi $[5,7,9,10,11,17,20]$. This study demonstrated the genomic heterogeneity of S. Typhi isolated from many areas in Indonesia. The study also showed that the isolates were not derived by clonal expansion from a single source. Despite being heterogeneous genetically, all $33 \mathrm{~S}$. Typhi isolates showed distinguishable phenotypes and were susceptible to all three antibiotics tested.

An interesting observation was that genome analysis using PFGE could detect mobility and movement of $S$. Typhi. Those isolates included in cluster IB1 possibly originated from East Indonesia, except JKT9, which might have occurred in Jakarta due to the migration of people from east to west Indonesia. A previous investigation reported that $S$. Typhi isolates from Indonesia were found to share some characteristics with those from Malaysia and Thailand [5]. Similarity and dissimilarity of $S$. Typhi isolates from Indonesia, Malaysia and Thailand showed that not only was the $S$. Typhi genome plastic, but also that there was a migration of $S$. Typhi in Southeast Asia [6, 7]. Additionally, PFGE techniques were able to detect particular $S$. Typhi strains which travelled quite a distance to El Salvador, Mexico, and Bangladesh [21].

In conclusion, DNA fingerprints of $S$. Typhi produced by PFGE showed the presence of endemic strains in localized geographic area in Indonesia as well as the movement of one strain type throughout the archipelago.

\section{Acknowledgements}

My special thanks to Dr. VNKD Kalay from the Department of Microbiology, Faculty of Medicine, Christian University of Indonesia for collections of $S$. Typhi from Jakarta and her excellent laboratory works, and to Dr. C. Simanjuntak from the Centre of Health Research and Development, Ministry of Health, Republic of Indonesia, for providing collections of $S$. Typhi from Makasar, Pontianak, Medan and Jayapura. I would also like to thank Professor Dr. S. Antonius from the Inter University Centre for Biotechnology, Institute of Agriculture Bogor, Indonesia, for providing the DNA marker Rhodobacter sphaeroides.

\section{References}

1. Ivanoff B (1995) Typhoid Fever: Global situation and WHO Recommendations. Southeast Asia J Trop Med Public Health 26 (Suppl 2): 1-6.

2. CDC Indonesia. Ministry of Health Republic of Indonesia (2007) Typhoid fever prevalence.

3. Profile Health status of Province South Sulawesi, Indonesia. Ministry of Health, Republic of Indonesia (2007).

4. Jakarta Dalam Angka (1999) Jakarta. Badan Pusat Statistik 156-160.

5. Thong KL, Cheong YM, Puthucheary S, Koh CL, Pang T (1994) Epidemiologic analysis of sporadic Salmonella typhi isolates and those from outbreaks by pulsed-field gel electrophoresis. J Clin Microbiol 32: 1135-41.

6. Thong KL, Puthucheary SD, Yassin RM, Pratiwi S, Padmidevi M, Soewandojo E, Handojo I, Sarasombath S, Pang T (1995) Analysis of Salmonella typhi isolates from Southeast Asia by pulsed-field gel electrophoresis. J Clin Microbiol 33: 1938-415.

7. Thong KL, Nair S, Subramaniam G, Puthucheary S, Yassin R, Cheong YM (1998) Genetic dynamics and molecular epidemiology of Salmonella typhi. Med J Indones 7 (Suppl 1): $147-50$.

8. Koay SA, Jegathesan M, Rohani MY, Cheong YM (1997) Pulsed-field gel electrophoresis as an epidemiologic tool in the investigation of laboratory acquired Salmonella typhi infection. Southeast Asia J Trop Med Public Health 28: 82-47.

9. Pang T (1998) Genetic dynamic of Salmonella typhi diversity in clonality. Trend Microbiol 6: 339-42.

10. Moehario LH and Soemanto RK (2001) Study of genetic diversity of Salmonella typhi using pulsed-field gel electrophoresis. Med J Indones 10: 158-163.

11. Soemanto RK and Moehario LH (2003) Analysis of pulsotypes of Salmonella typhi isolates and their clinical profiles in typhoid fever patients. Med J Indones 10: 13-20.

12. Suwanto A and Kaplan S (1989) Physical and genetic mapping of the Rhodobacter sphaeroides 2.4.1. genome: Genome size, fragment, identification and gene localization. J Bacteriol 171: 5840-5849.

13. Suwanto A and Kaplan S (1992) Chromosome transfer in Rhodobacter sphaeroides: $\mathrm{Hfr}$ formation and genetic evidence for two unique circular chromosomes. J Bacteriol 174: 1135-1145.

14. Bannerman TL, Hancock GA, Tenover FC, Miller JM (1995) Pulsed-field gel electrophoresis as a replacement for bacteriophage typing of Staphylococcus aureus. J Clin Microbiol 33: 551-555.

15. Zadoks R, Leeuwen W, Berkema H, Samdimon O, Verbrugh H, Schukken YH (2000) Application of Pulsed-field gel electrophoresis and binary typing as tool in veterinary clinical microbiology and molecular epidemiologic analysis of bovine and human Staphylococcus aureus isolates. J Clin Microbiol 38: 1931-1939.

16. Rohlf FJ (1994) Numerical taxonomy and multivariate analysis system, version 1.80. New York: Exeter Software.

17. Thong KL, Puthucheary SD, Pang T (1997) Genome size variation among recent human isolates of Salmonella typhi. Res Microbiol 148: 229-235.

18. Liu SL and Sanderson KE (1995) Rearrangements in the genome of the bacterium Salmonella typhi. Proc Natl Acad Sci USA 92: 1018-1022.

19. Sanderson KE and Liu SL (1998) Chromosomal rearrangements in Salmonella typhi spp. Med J Indones 7 (sppl 1): 30-37. 
20. Thong KL, Goh YL, Yasin RM, Lau MG, Passey M, Winston G, Yoannes M, Pang T, Reeder JC (2002) Increasing genetic diversity of Salmonella enterica serovar typhi isolates from Papua New Guinea over the period from 1992 to 1999. J Clin Microbiol 40: 4156-4160.

21. Kubota K, Barrett TJ, Ackers ML, Brachman PS, Mintz ED (2005) Analysis of Salmonella enterica Serotype Typhi Pulsed-Field Gel Electrophoresis patterns associated with International travel. J Clin Microbiol 43: 1205-1209.

\section{Corresponding author}

Dr. Lucky H. Moehario, PhD

Department of Microbiology

Faculty of Medicine

University of Indonesia

Jalan Pegangsaan Timur no. 16, Jakarta 10320 Indonesia

Email: luckyhmoehario@gmail.com

Conflict of interest: No conflict of interest is declared. 